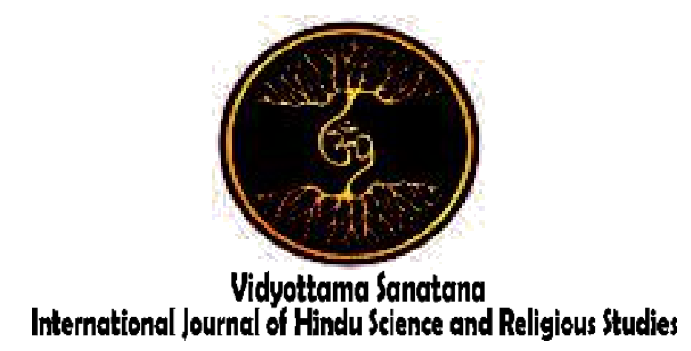

Vol. 4 No. 1 May 2020

\title{
THE IMPLICATIONS OF THE TEO-FEMINISM EDUCATION IN THE EPIC OF MAHĀBHĀRATA FOR READERS
}

\author{
By: \\ Ni Made Anggreni ${ }^{1}$, I Wayan Sukayasa ${ }^{2}$ Ni Made Indiani ${ }^{3}$ \\ ${ }^{1}$ Universitas Hindu Negeri I Gusti Bagus Sugriwa Denpasar \\ ${ }^{23}$ Universitas Hindu Indonesia \\ E-mail : ${ }^{1}$ madeanggreni74@gmail.com, ${ }^{2}$ iwayansukayasa33@gmail.com, \\ 3indianimade@gmal.com
}

Received: May 13, 2020

Accepted: May 25, 2020

Published: May 30, 2020

\begin{abstract}
Women increasingly develop themselves into the same human as their husbands (men). However, in view of this phenomenon, it can be seen that among the progress of women there are still gender gaps in women's daily lives. In addition to seeking self-nature, women are also required to be able to manage the situation of the household, the needs of children, and to participate in activities in the community. One solution that can be done so that the gap can be minimized, namely between men and women can complement each other by reflecting on religious teachings. One of them is the teachings contained in literature, the epic Mahābhārata. This research is examined based on the perspective of Hindu religious education with the aim of analyzing the implications of theo-feminism in the epic of Mahābhārata (perspective of Hindu religious education). This research was analyzed by qualitative descriptive method with interview and documentation data collection techniques. The findings in this study are that women not only play a domestic role but also play a social role, the struggle for gender equality, and the occurrence of karmic phala. The implications for the reader, namely the implications of leadership, politics, culture, and education.
\end{abstract}

Keywords: Educations; Teo-Feminism; The Mahābhārata Epic

\section{INTRODUCTION}

Education for humanity is an absolute necessity that must be fulfilled throughout life. It is impossible for humans to live, develop, prosper and be happy without it because humans are born helpless and they do not have the perfect instinct to adapt to the environment. Humans need a long learning period in preparation to be able to properly connect with the environment constructively, 
which begins after the human child reaches physical adjustment like being able to walk, eat, use his own hands or achieve physical freedom. Humans must be educated or he will lose the essence of humanity and will not become cultured (Maksum, 2016: 33).

Adults provide education for their children to increase the maturity of children, both boys and girls. Women increasingly develop themselves into human beings who will be equal to the men. Women can be leaders who can decide and determine, not just accept everything as before. They can even have better careers than their husbands, like being school principals, regents, police chiefs, ministers and council members. This situation will also affect the characters of a woman. Besides, the bustle of women also has an impact on children's education at home. Because of it, their children are sometimes taken care by household personal assistants. Mother gives money as a substitute or a symbol of affection. Giving money that is less proportional to children because there will be a tendency to be misused which has a bad impact on the child's behavior and character.

In view of this phenomenon, it can be seen that there are still gender gaps in women's daily lives. In the effort to find the nature of life, women are also required to be able to control their household, fulfill the needs of the children and participate in community activities. One solution that can be done in order to minimize the gap between men and women is by complementing each other, especially by reflecting on religious teachings contained in literary work.

Literary work is one of the results of an immaterial culture that contains various general teachings such as science, history, mythology, behavior, customs, morals, religion, philosophy and so forth. In its development, many literary works appeared in various forms in accordance with their era (Emzir, 2015: 6).

One of well-known literary works is the epic of Mahābhārata by Rishi Vyasa. Female figures in this epic such as Gangga, Satyawati, Draupadī, Kunti, Gandarī and Śhikhaṇụi are described as women who never give up even in the most difficult conditions because they believe in the miracles of God. In the first impression, it is very clear that Mahābhārata is a story of brothers fighting over the throne of Hastinapur - along with all the patriarchal values which have no place for women, except as wives or mothers for their sons.

However, the more a person delves into the Mahābhārata text, the more one will find courage in women such as Gangga, Satyawati, Draupadī, Kunti, Gandarī and Śhikhaṇdi through their roles. Over the various situations that cornered them, the women exerted their minds and bodies to fight in their own battles with a firm and unyielding attitude. They created their space and played decisive roles that left men with no choice but to walk along the paths that had been set by women. The women are described as having special heroic qualities and we cannot help but feel sympathetic and awe for their wisdom, skill, intelligence and passion for achieving something not only the best that life has to offer but also achieving it in a way which they already set. Therefore, behind every successful man, there is a strong and ideal woman.

\section{METHOD}

The main focus of this research is the epic story of the Mahābhārata by Subramaniam. This research belongs to the qualitative category. The types of data are quantitative data and qualitative data. The primary data source of this research is the epic Mahābhārata by Subramaniam while the supporting data are in the form of related literature. Researchers as the main instrument source. Data collection techniques with documentation and interview studies. The data analysis technique is done by reading the Mahābhārata epic story, using a qualitative descriptive method.

\section{III.DISCUSSION}

\subsection{Leadership Implications}

Draupadī was the only Hastinapur woman who managed to question patriarchal norms, openly challenged men and assert that she was equal to them. On many occasions, it was 
Draupadi who defended or even protected her husband and not vice versa. In fact, her husbands, especially Yudhistira, disappointed her at critical moments: when Draupadī was stripped off her clothes in the Kuru palace, kidnapped by Jayadrata and harassed by Kicaka at the Wirata palace. Regardless of all Draupadī's insults, the Pandavas tended to seek a peaceful path rather than revenge. Even on the final journey to the Himalayas, when Draupadi fell, none of them stopped to help her. But despite all the difficulties she experienced, Draupadi remained strong and managed to carve her name in this epic (Sharma, 2013: 86-87).

Draupadi was a woman born of fire. According to the prophecy, she would destroy the Kshatriyas (warriors). She became equal to men when she decided to marry the five Pandavas. On several occasions, the Draupadī protected and provided livelihood for her husbands. Thus, the character of Draupadi can be applied in modern life which is protective, no matter who they are, both men or women. She also denied the patriarchal system in the Mahabharata story to be considered as a dissident. Draupadi just wanted to align women's degrees with men. That is what modern women must put forward in living their lives that men do not merely protect them, but they actually have the strength to defend and protect themselves. Being independent and tough in facing all problems is a must. Likewise, when Draupadi faced harassment in the hall when Yudhisthira lost the dice game. The following is the excerpts of the story in which Draupadi was able to release her husband from Kaurava's slavery.

"... I apologize for the actions of my son who did not know what he had done". Draupadi said "Give me this gift, release my husband Yudhisthira from this attachment". I beg you to announce that he is not a sinful slave." Dhrtarastra did that. He asked her to ask for another request. After that Draupadi freed Bhima, Arjuna, Nakula and Sahadeva from their ties. "Ask for another gift, my daughter." Dhrtarastra said this to cheer him up with this gift (Subramaniam, 2007: 190).
Draupadi was always able to control her husbands to improve their abilities in preparing for the war that would possibly occur. Besides, Draupadi was also able to make her husband remember the oaths they took when he was harassed in the dice game hall by Duryodhana, Radheya, Dursasana, Sakuni and the other Kauravas. She is always able to provide motivation.

Furthermore, the female figure who was able to become a leader was Śhikhandi. She was the only woman who was given the right to engage in the Barathayuda (the great battle of Kurukshetra). This opportunity was used by Śhikhandi as best she could to defeat Bhishma. Shikhandi opened the way for the Pandavas' victory over the Kauravas. For this reason, she was named the main woman who was capable of entering the Mahābhārata. The following is excerpt of the story taken from a book by Subramaniam (2007: 526) which tells the moment when Bhisma realized that someone invited by Arjuna into his chariot was reincarnation of Princess Ambha.

Śhikhanḍi approached Bhisma. She challenged Bhisma. Bhisma smiled mockingly at her. He said "You might be a man now. You may be a great man. But to me, you are a woman. I don't like to fight with women. I will not accept your challenge."

Based on the excerpt above, it can be considered that the spirit of Śhikhandi is worthy of notice when she was able to carry out the mission given by Pandavas in order to defeat Bhisma by shooting five sharp arrows. This attitude is worth being emulated by a leader in carrying out leadership. Bhagavad Gita, III.21 tells

yad yad ācariti śreșthas, tat tat evetarojanah,

Sa yat pramānam kurute, tokas lad anuvartate

Meaning:

Whatever deeds are carried out by great people, will be followed by ordinary people. Any standard set by his actions as an example, followed by everyone (Darmayasa, 2017: 110-111). 
Based on the explanation above, it can be interpreted that a good leader will make his subordinates become good. If a leader is disciplined, his subordinates will also be disciplined. A leader will not be able to get his subordinates to be on time, if he is always late or he cannot be on time. This is based on people's thinking that someone can be far better than someone else and/ or can be far worse than someone else. It is also related to the leadership on how a leader can establish an organization or company well if he has not been able to be a good model to his subordinates. Therefore, based on the function of leadership to mobilize an organization, there are four terms that we encounter; commanding, directing, actuating and motivating. It seems that the ability possessed by Draupadi and Śhikhandi is a way for them to mobilize their husbands, friends and the state to keep their spirits so that this motivational spirit will be very suitable to be emulated by women. It also hopes that women who have become mothers are required to be able to motivate their children and husbands in life.

\subsection{Political Implications}

Education is very important for women. Broad insight makes a woman become smarter and wiser in living or making decisions in their life. In conveying aspirations in front of the community, good speaking skills are needed to be able to touch people's hearts. Women have a great asset for it, namely the maternal instinct that makes women look soft in speech. In addition, intelligence is also needed in choosing words, so that people can understand them.

Broad insight, gentleness, intelligence and high knowledge make women look more perfect in front of society. Indonesian politics is more often identified with the world of men. This happens because politics is considered as an activity in which people need "power" to compete, full of intrigue and inappropriate for women to enter. Politics becomes an activity that is synonymous with negative power, abuse, violence, mobilization and open competition in which conditions are not inherent in women or even their feminine side that prioritizes peace. Even though when talking about power, it is actually neutral because it can be used for good or bad.

The ability to join politics of a woman is also stated in the epic of Mahābhārata. It can be seen when Satyavati wanted her descendant to be king. Satyavati and her father were able to make Bhisma to withdraw his rights as a crown prince and took an oath to be single for the rest of his life as in the story below.

Is there any guarantee for me if they will not claim Satyavati's child rights in the future? Prince was surprised at the man's great desire. With a disgusted smile he said "Are you not satisfied? I will satisfy your heart. I will not marry. I swear by heaven and earth, or the name of my teacher Dharma that I will not marry as long as I live. Are you satisfied now?" (Subramaniam, 2007: 10).

Mahābhārata recognizes the strength in women. Anyone must deal with women if they want to maintain the throne. This is why Yudhistira, the new king who was anointed after Bharatayudha, asked Bhishma who was lying on an arrow bed, to tell him about the intricacies that tended to be the root of all evil and was considered as the weakest point. Marriage, family, and mother's role are sacred. These can be important for the welfare of a state. If the norms relating to these sacred things are threatened and disturbed, life will turn into chaos soon (Sharma, 2013: 8).

Women's sexuality is potentially considered as a very destructive force, even the most powerful men can be helpless. However, women's power can be crucial if it is controlled and regulated. Therefore, women are divided into two classes which are truly destructive because of their uncontrolled sexuality and sacred wives and mothers. In this polarity, there is ambiguity towards niyoga or getting out of bed, polyandry, and women's freedom to take the initiative in approaching a man. There is also ambivalence related to the relationship between wife and her brother in law. 
Mahābhārata presents a variety of women. Their words and actions become the driving force behind men's behavior. They continually intervene, engineer, conquer and undermine to create space for themselves to transfer power. Men probably think that they control women and they are superior to women, but in Mahābhārata, women are intelligent, brave, and beautiful individuals who cannot be easily persecuted.

\subsection{Cultural Implications}

\subsubsection{Implications for the Preservation of Performing Arts}

The theo-feminism education in the epic of Mahābhārata has also been performed in the form of fragment dance by Pradnya Swari Bali Dance Studio led by Sudiksa. The fragment dance that was performed at the Bali Arts Festival (PKB) in 2017 presented a performance that tells the insults to Draupadi in the gambling arena. According to the leader of the Sudiksa's studio, he had to read and understand the epic of Mahābhārata especially when narrating the Dursasana's scene when pulling Draupadi's saris in the gambling arena. Furthermore, Sudiksa said something as follows.

To perform the scene of Draupadi's insults, it takes a long time to practice the dance and music. I also have to understand the story of the Mahābhārata. I read the Mahābhārata book over and over again, ponder it, imagine the figures of the characters, especially Dursasana and Draupadi for days. Then, the results of that reflection, I presented in the form of art performances. Of course, it's not perfect at all. However, rather than nothing, it is better to provide entertainment and messages to the audience (Interview, 3 May 2019).

Besides traditional Balinese artists, there are many artists from outside Bali utilize the story of Mahābhārata for performing arts. Draupadi's character is very interesting and has no counterpart right now. Sudiksa could judge Draupadi's character to be very interesting and there was no equivalent at this time. It is a sign that he has made a vision and contemplation of the figure of Draupadi in the story of Mahabharata. From the results of that contemplation, he presented the figure of Draupadi in performing arts. Thus, the theofeminism education in the epic of Mahābhārata has implications for the preservation of the performing arts.

\subsubsection{Implications for Literary Arts}

Teo-feminism education in the epic of Mahābhārata which created literary work is when the prayer of a mother took Arjuna to conduct asceticism on Mount Indrakila. The prayer of a woman or mother has a strong suggestion of influence to determine one's success. This can be an evidence in the story of Arjuna when he asked for powerful weapons from the Gods in preparation for Bharatayuddha that would take place soon. Rajagopalachari wrote something as follows.

Upon the advice of Bhagawan Wyasa, Arjuna went to Mount Himalayas to be an ascetic and wanted to be blessed with new weapons by the gods. He excused himself to his brothers and Panchali. Panchali said, "Dananjaya, may you succeed in carrying out your duties. May the Gods give you everything that your mother, Queen Kunti craves since a long time ago. Our happiness, honor and prosperity all depend on you. Come back after successfully getting new weapons." Thus Panchali delivered Arjuna with encouraging words.

Although the words came from the mouth of Draupadi, his wife, the hopeful prayer was the prayer of his mother, Queen Kunti. "May the Gods give you everything that your mother, Queen Kunti craves since a long time ago." (Rajagopalachari, 2013: 142)

Arjuna found success in his quest for a new magic weapon from the Gods. He said about various experiences, both bitter and sweet experiences while in the heaven. $\mathrm{He}$ also gained new experience which is to add skills in terms of dancing and playing music. $\mathrm{He}$ also told of his practice against Nivatakavaca in a beautiful and prosperous 
state. Subramaniam (2007: 239) writes Arjuna's experience as follows.

I'm very happy there. One day, Lord Indra told me. "You have to do something to serve me. There are several asuras called Nivatakavaca. They have made many difficulties for me. They live in the middle of the deep sea. They are not invincible until now. I want you to go, fight and destroy them."

Arjuna was then told to fight with Nivatakavaca. In a fierce battle, Arjuna managed to gain victory. Then Arjuna continued his story (Subramaniam, 2007: 240).

After killing Nivatakavaca, I entered their city. That city is very beautiful. There are no words that can describe it, no one can describe the prosperity, the luxury and wonders of that city. I was very surprised to see that attractiveness. I asked Matali how the city can be so prosperous. Amaravati is not as beautiful as that city. Matali told me that the city belonged to Lord Indra. However, the city was taken by the Nivatakavaca who had pleased Brahma because of their asceticism. They were invincible. The gods cannot do anything to them, thanks to the grace of Brahma. This is why my father wanted me to go to that place and kill them. I am a human and not a god. We return to the city of Lord Indra, Amaravati."

The story of Arjuna's experience of asceticism and living life in the heaven, apparently caught the attention of $\mathrm{Mpu}$ Kanwa. This poet wrote this literary work during the reign of King Airlangga who ruled in East Java from 1019 to 1042 AD. While this kakawin was estimated to be composed around 1030. Experts strongly suspect that the story of Arjuna Wiwaha was taken from Wanaparwa, the third book of the epic of the Mahābhārata. Listening to the story of Arjuna Wiwaha, it can be said that MPU Kanwa gave some additions and also reduced stories that were presented by Indian culture, both written by Rajagopalachari and Subramaniam. The summary of the story contained in Kakawin
Arjunawiwâha based on Zoetmulder's review (1995: 298-302) can be seen as follows.

Niwâtakavaca, a giant (daitya) prepares himself to attack and destroy the Lord Indra's heaven. Lord Indra decided to ask for help from a human because the giant could not be defeated, either by a god or by a giant. Arjuna was chosen who lived as an ascetic on Mount Indrakîla. Before Arjuna was assigned, his fortitude must be tested in doing yoga first because this is also a guarantee that his help actually brings results as expected.

Seven angels whose beauty was truly amazing were called. Two angels, Suprabhâ and Tilottamâ, were ordered to visit Arjuna and then used their beauty to seduce him. Those angels traveled along the natural beauty of Mount Indrakîla to meet Arjuna. They rested in a river, beautified themselves and planned something best to achieve their goals.

The angels arrived at a cave where Arjuna sat cross-legged to do samadhi. They then showed all the beauty to attract Arjuna, but in vain. The angels who intended to tempt Arjuna were tempted by Arjuna's good looks. It was disappointing. They returned to heaven and reported to Lord Indra. For the gods, the angelss failure was joy because it was a proof of Arjuna's determination.

Lord Indra himself then visited Arjuna and disguised himself as a senile and hunched old sage. The old sage pretended to cough and then was respectfully greeted by Arjuna. In the spiritual dialogue, Arjuna asserted that his only aim in doing asceticism was to fulfill his obligations as a knight and helped his brother, Yudisthira to reclaim his kingdom for the welfare of the whole world. Lord Indra was satisfied to hear Arjuna's answer. He showed himself and suggested him to ask for grace from Lord Shiva. Lord Indra returned to the heaven and Arjuna continued his asceticism.

In the meantime, the king of the giants had heard the news of what had happened on Mount Indrakila. He sent a giant named Mûka to kill Arjuna. In the form of a wild boar he destroyed the surrounding forests. Arjuna was startled, raised his weapon and exited his cave. At the same time Lord Shiva appeared in the form of a hunter from one of the 
estranged tribes, the Kirâma. At the same time, they released their arrows and a boar died because an arrow pierced. The two arrows turned out to be one. A dispute arose between Arjuna and the Kirâma over the wild boar. Disputes culminated in fierce warfare. Because of running out of arrows, they then started fighting with their bare hands. Arjuna, who almost lost, held his opponent's leg. At that moment, the hunter's form vanished and Lord Shiva appeared.

Lord Shiva presented Arjuna with a powerful arrow named Pasupati. At the same time, Arjuna was also given magical knowledge how to use the arrow. After that Lord Shiva vanished. Then two apsara (demigods) came and brought a letter from Lord Indra. He asked Arjuna to appear, assist the gods in their plans to kill Niwatakavaca. Arjuna was doubtful because this meant that he was even longer separated from his brothers. However, he finally agreed. He wore a magic cloth with a pair of sandals carried by the two apsara. They flew to the heaven to meet Lord Indra. He was greeted cheerfully and the angels were infatuated by Arjuna's good looks. Lord Indra explained that the situation was not so favorable for the gods due to Niwatakavaca's evil plan. The giant could only be killed by a human, but they should first find their weakest point. The angel, Suprabha who has long been targeted by the giant, would visit him accompanied by Arjuna and tried to know his secret. Arjuna accepted the assignment and they came down to earth. In the afternoon, they arrived at the giant king's house. The giants were holding preparations for the war against the gods there. Suprabha headed to a studio of mestika (pure crystal hall) in the middle of the palace courtyard while Arjuna was following her closely. In fact, Arjuna had a secret power so he could not be seen by people. That was why the ladies-in-waiting who were mingling in the full moonlight only saw Suprabha. Some of the ladies-in-waiting who had been brought here from Lord Indra's palace recognized her and welcomed her happily while asking how things were happening in heaven. Suprabha told how she left the heaven and crossed to
Niwatakavaca of her own volition because it would be destroyed or before she and all the spoils were taken prisoner. Two ladies-inwaiting came to the king and brought news that he had longed for. Instantly he got up and headed to the Sari garden. Niwatakavaca held Suprabha. Suprabha rejected all his lustful urges and begged the king to be patient until dawn. She seduced him while praising the power of the invincible king, then asked what kind of results in which he was awarded an extraordinary miracle by Rudra. Niwatakavaca was trapped by Suprabha's persuasion and revealed his secret. The tip of his tongue was his sacred place. When Arjuna heard that he left his hiding place and destroyed the palace gate. Niwatakavaca was shocked by the terrible noise. Suprabha used the moment and ran away with Arjuna.

The anger of the king overflowed because he realized that he had been deceived. He ordered his troops to immediately depart and march against the gods. The heaven was filled with joy because Arjuna and Suprabha had returned safely. In a rally held by the gods, the tactic of repelling the enemy was discussed, but only Lord Indra and Arjuna knew what weapons they had in possession of Niwatakavaca's inadvertent remarks. Armies of the gods, apsara and gandharwa headed to the battlefield on the southern slopes of Mount Himalaya. When the king of the giants began chasing him and shouting in anger, Arjuna pulled his bow. The arrow shot into the king's mouth and pierced the tip of his tongue. He fell down and died.

Arjuna received a prize for his helps. For seven days (according to calculations in the heaven and this is the same as seven months on human earth) he was given the fruit of the results of his manly behavior. He would reside like a king on the throne of Lord Indra. After being crowned, he married the seven angels. One by one, escorted by Menaka, they entered the bridegroom's room. The first angel was Suprabha because she had the first right after their dangerous journey. After Suprabha, Tilottama arrived as the second and followed by the other five angels whose their names were not mentioned. 
After all this time, Arjuna began to get nervous. He missed his relatives he left behind. He locked himself in a hall in the park and tried to express his feelings through a poem. That moment attracted Menaka and Tilottama's attention. The latter stood behind a tree and listened how Arjuna found difficulties to compose the second couplet's closing line. Tilottama then finished it off with a funny line. After seven months had passed, Arjuna begged Lord Indra for farewell. He was escorted back to earth by Matali in a heaven chariot.

Listening to the story of Arjuna in the Kakawin Arjuna Wiwaha, it is certain that Mpu Kanwa had read intently and deeply the epic of the Mahābhārata from India. When referring to the Mahābhārata written by both Rajagopalachari and Subramaniam, Mpu Kanwa gave additional figures, such as the seven angels who seduce Arjuna. The names of the seven angels like Suprabha, Menaka, Tilotama and the other four angels are not mentioned in the epic of Mahābhārata, either written by Rajagopalachari or Subramaniam. In the epics written by these two Indian poets, there are no stories of seven angels seducing Arjuna. Likewise Arjuna's marriage with seven angels in heaven was not told either by Rajagopachari or Subramaniam. On the contrary, Subramaniam (and this is not told by Rajagopalachari) tells the story of Urwasi who fell in love with Arjuna. She cursed Arjuna to be a sissy for a year because of being rejected by Arjuna.

Mpu Kanwa seems more inclined to follow the story told by Subramniam. That can be seen from the story of Nivatakavaca. However, in the text written by Subramaniam, there is no mention that Arjuna fought against Nivatakavaca with Suprabha. Likewise, Subramaniam did not tell the point of Nivatakavaca's weakness which was on his tongue. The story told by Mpu Kanwa through Kakawin Arjuna Wiwaha shows that writing literary works was inspired by the theofeminism education in the epic of Mahābhārata. Mpu Kanwa is certainly one of the readers of the epic of Mahābhārata. Then through his inner strength and imagination, he wrote the story again in the form of kakawin (literary works). In general, the definition of kakawin is a form of poetry in old Javanese language with meters originating from India. Usually a kakawin in a certain meter consists of at least one stanza. Each kakawin stanza has four lyrics with the same number of syllables and usually consists of guru and laghu. Guru is a term from Sanskrit which means heavy voice or high voice, while laghu is light voice or short voice.

In the kakawin meter, a syllable containing long vowels (a, i, u, e, o, ai and au.) is called a long syllable or guru, whereas the syllables that contain short syllables are called laghu. According to C.C Berg, Old Javanese kakawin has many similarities with kavya, Indian poetry in Sanskrit. Kakawin can be interpreted as old Javanese poetry which uses the time meter "kavya" of Indian poetry (in his book entitled: Indleding tet de studia van Oud Javaabsch, 1928).

Morphologically, the word 'kakawi' is formed from the basic word ' $k a w i$ ' with an affix in the form of a conflict (ka-) $+(-n)$. The base word of 'kawi' lexically means the author or poet (Woyowasita, 1973: 66), conflkict $(\mathrm{ka}-)+(-n)$ in the old Javanese morphological system means to declare things to be like the so-called basic words or also support the meaning of rules, status as referred the basic word. Thus, the word 'kakawin' means being a kawi or poet.

Etymologically, the word 'kawi' means clever, smart and creator. Kakawin is old Javanese poetry. The meaning of kakawin comes from the word $k a=k a w i=e n$ which means poet. Kakawin itself can be interpreted as poetry. The book that reveals about kakawin is known as wrettasancaya. This wrettasancaya book was published by $\mathrm{H}$. Kern in 1875 with Javanese letters. This book was also re-published in Latin letters which had been published in Verspreide Geschriften, volume IX, page 67.

Based on the description above, the theofeminism education in the epic of Mahābhārata has implications for the preservation of literary works, especially old Javanese literature. Besides kakawin, the 
theo-feminism education in the epic of Mahābhārata also has implications for the preservation of geguritan literary works. The readers of the epic of Mahābhārata Epic who devoted themselves to regional literature wrote a geguritan literary work in accordance with his imagination. The geguritan that has a close connection with the theo-feminism in the epic of Mahabharata is the Geguritan Salia. It is not clear who the author of this geguritan is. Some sources say Ida Anak Agung Made Regeg was the one who popularized this geguritan. Geguritan was originally formed from the poems of Sinom and Pangkur. In its development, this geguritan received additional support from several other Balinese literary observers. Maharani (2001: 41) then gave an additional poem with the intention that the geguritan lovers in sekaa santi would not feel bored. Besides Sinom and Pangkur, the geguritan of Salia was awakened from the poems of Semarandana, Ginada, Dangdang, Ginanti, Durma, Adri, Maskumambang, Demung, and Megatruh. Despite the addition of the poem, the contents of the story have not changed from the previous book.

Then the reader Mahābhārata, I Wayan Sutedja from Buruan Village, Penebel District, Tabanan Regency copied the geguritan entitled Geguritan Sang Salya Senapati. The followings are the excerpts of that geguritan found at the end of its part, namely Pupuh Sinom in the serial numbers 38 to 43 .

38. Maatur Ni Sugandika, "Titiang mapamit mawali, ka puri Madra nêgara, erang titiang kari urip, katêmu ring wong nêgari, suka yan ngemasin lampus, mangiring cokor i dewa", ngandika Sang Satiawati, "Yaning tuhu, nyai pitrêsna ring nira.

39. Nah jalan jani gatiang, bêsikang idêpe jani, mangiring raja dewata, da ja buin walang ati”, Ni Sugandika tur agêlis, ngalungsur duhung sang prabu, Sang Satiawati umayat, ring dada tungtunging kêris, agêlis mur, lintang sudira ring cita.
40. Ni Sugandika kocapan, nemangkin mangagêm kêris, raris ya mangeka cita, ngastawa sri narapati, sudira tan ana wêdi, ature "Ratu Sang Prabu, mangkin jantos ratu titiang, kaula bakti mangiring", gêlis nyuduk, sêrira wawang ya pêjah.

41. Saking gêlising cêrita, Sang Satiawati newati, dening mula ida satia, Ni Sugandika mangiring, subaktine tan sinipi, kaeman antuk sang prabu, Sang Satiawati nyayangang, punika awinan lalis, tan kaitung, lêwih purine ring Madra.

42. Cêrita mangkin sang atma, tansah adulur mamargi, Sang Salia rauh mamêndak, atmane Sang Satiawati, Sugandika mangiring, Sang Salia ngandika alus, "Suwe titiang manyantosang, i dewa tan wentên prapti, nunas ratu, dumununging maring suarga".

43. Nemangkin ida Sang Salia, widiadara mamêndakin, mantuk ka Sura-buana, widiadari akueh ngiring, tan kawarna nemangkin, cêrita ring Suarga murub, baswara ngulap-ulap, sarwa ratna mirah adi, sampun puput, Sang Salia manggih suarga.

According to Salya's geguritan above, we can see the addition of figures in the epic of Mahābhārata. In the epics of Subramaniam and Rajagopalachari, there is no Satyawati figure as Salya's wife, but Satyawati's name was known as Bhagawan Parasara's wife who gave birth to Bhagawan Wyasa. Satyawati was also Sentanu's wife who gave birth to Citrangada and Vicitrawirya. In Indonesian culture, especially Javanese and Balinese, the marriage of Satyawati and Salya has its own story. Jero Dalang Wayan Supartha said there lived a giant-faced sage named Rishi Bhagaspati in a pasraman in the forest. Because of following Dharma ways, he is also named the giant Dharma. He had no wife. When he wanted to have a child, he worshiped and begged the Gods. The Gods granted him 
a beautiful princess. Because she was from the worship, the child was named Pujawati.

After Pujawati became an adult, she wanted to get her soul mate. One night she dreamed of meeting a handsome young man. Pujawati asked her father to look for the young man she met in her dream. Rishi Bhagaspati went around looking for that young man. On the way, Rishi Bhagaspati met a handsome young man named Narasoma. The young man was asked to be Rishi Bhagaspati's son-in-law, but he refused outright. Narasoma said if his father had a form of a giant, then his daughter should be a giant, which was certainly not beautiful. Rishi Bhagaspati finally forced Narasoma by carrying him. After arriving at his pasraman, Rishi Bhagaspati introduced his daughter, Pujawati. Apparently, Narasoma was surprised and mesmerized to see the beauty of Pujawati that could be described like an angel.

In short, Narasoma wanted to marry Pujawati. After a while they enjoyed the happiness of a household, Narasoma suddenly felt sad when enjoying food. Narasoma explained that there was latah in the rice. Pujawati looked for latah, but she found nothing. Upon Narasoma's suggestion, Pujawati conveyed this to her father, Rishi Bhagaspati who was intelligent and wise. $\mathrm{He}$ understood immediately and asked his daughter whether she chose her father or her husband. For the sake of the future life, Pujawati chose her husband. Because of her loyalty to her husband, Pujawati was later named Satyawati.

After that moment Rishi Bhagaspati excused himself to return to the heaven. Before disappearing, Rishi Bhagaspati told Narasoma about the history of his life. Rishi Bhagaspati said he was the incarnation of Suksrana and Narasoma as his biological brother, Sumantri. Sumantri wanted to study with Arjuna Sasrabahu, but he did not want to take his sister to Arjuna Sasrabahu's palace because Suksrana had a ugly face. However, Suksrana insisted to go to that place and Sumantri frightened his brother with arrows. Unexpectedly, the arrow released from his bow and pierced Sukasrana's body until he died.
In the next incarnation, Suksarana became Rishi Bhagaspati and Sumantri became Narasoma. Rishi Bhagaspati wanted to meet with the incarnation of Sumatri again. That is why he created a princess by doing worship. However, after meeting again, Narasoma did not want to live together with the incarnation of Sukasrana. Narasoma's attitude in Balinese is referred to as a "sale" tree in which the flowers are used as hair ornaments, but the stem is "dikiladin" (used as a butt cleaning tool after defecating). Therefore, Narasoma was named Salia (often written Salya) which is derived from the word "sale". Rishi Bhagaspati then swore an oath that he would kill Salya in war through his forthcoming incarnation. According to the story, Rishi Bhagaspati or Giant Dharma incarnated as Yudhistira. Because of that reason Yudhisthira was the only one who could defeat Salya at the time of the Bharatayuddha War and the king of Madra already knew it too. It can be seen in Geguritan Salya. When word got out that Salya was named Senapati (war commander), Nakul immediately went to his uncle. Nakul said that he would not be able to fight his uncle. Therefore, Nakul begged Salya to kill him right now. However, Salya said that he would lose the war if Yudhisthira resisted and used the weapon of Kalimausadha. In the epic of Mahābhārata, Salya indeed died at the hands of Yudhistira.

In Geguritan Salya, Satyawati is not the only additional figure, but there is also a figure named Ni Sugandika as Satyawati's servant. Satyawati who was very loyal to her husband, finally committed suicide after meeting her husband's body on the battlefield. Likewise Ni Sugandika also committed suicide because he was very loyal to her Lady.

With the addition of the figures and stories written earlier, it shows that the implications of Teo-Feminism education in the epic of Mahābhārata have an influence on the preservation of regional literary arts. The geguritan was written by the reader of the epic of Mahābhārata who had a talent for composing literary works. 


\subsection{Educational Implications}

Education as a noun means the process of changing attitudes and behavior of a person or group in an effort to mature humans through teaching and training. The term 'education' is terminologically defined differently by education experts. This difference is influenced by their own perspective.

Education is closely related to all aspects of human development, such as physical development, health, skills, thoughts, feelings, volition, social and the development of faith. This development makes humans more perfect, improve their lives, natural life becomes cultural and moral (Gandhi, 2011: $65)$.

The theo-feminism education in the epic of Mahābhārata for the readers has provided possiblities and opportunities for the readers to think and reflect on the messages conveyed in the story. Scenes in the epic of Mahābhārata especially those relating to theofeminism have received much readers' reflection. Moreover, Mahābhārata readers not only get messages through written stories, but also from serial films that are shown on television and on DVD that have been commercialized in the public market. From some books, there is a lot of readers' reflection, especially when the Goddess Ganga threw her babies into the Ganga River as soon as they were born.

There are messages that become the reader's contemplative material that can be picked from the narration. According to a number of informants, there are at least three things that are taken as contemplations, such as the belief in punarbawa (incarnation), the law of karmaphala law and moksa. According to Gede Anis, an artist in Tabanan, in the story that tells us about the Goddess Ganga, there are at least two things that can be learned, namely the belief in the incarnation and the law of karmaphala.

Gede Anis further conveyed his contemplation that not only the story of the Goddess Ganga can give credence to the incarnation but many other stories in the epic of the Mahābhārata. For example, the birth of Princess Amba became Śhikhaṇdi. Because of being disappointed by by Bhisma, she was born as a hero to take revenge. Likewise, Bambang Ekalaya who was cheated by Rishi Drona was reborn as Dristajumna. Rishi Bagaspati who is often called the Giant Dharma in Bali was born as Yudhisthira.

The story of the Goddess Ganga who gave birth to Bhisma also led to reflections that the existence of the law of karmaphala must also be believed. This was stated by Ketut Sudira, a stakeholder from Pedungan, South Denpasar. After he read the Mahābhārata and its stories which were told orally, the story of the Goddess Ganga implies the law of karmaphala. It can be listened to when the birth of the vasu. In the epic of Mahābhārata compiled by Subramaniam, it is not mentioned the birth of the vasu. The story of the eighth birth of the vasu is told in the epic of Mahābhārata compiled by Subramaniam. According to Ketut Sudira, the epic of Mahabhrata implies the law of karmaphala. Based on the story, there were eight vasu stole the Rishi Wasistha's Nandini cows when walking in Rishi Wasistha's pasraman. Because of that dishonorable deed, Rishi Wasistha cursed the vasu to reincarnate to be human beings. They then asked for help to Goddess Ganga to make them her children when they were born in the world. Rishi could not remove the curse, but he could minimize it. Prabhasa Wasu who took Wasistha's cows got the severest punishment to live in the world longer, while the other seven vasu only live a day in the world who because of their small mistakes. That is why when the Goddess Ganga gave birth, her first seven sons were banished to the Ganga River, so that they would soon be free from punishment for their return to the heaven, while Prabhasa vasu whose greatest sin was born as Bhisma. Furthermore, Ketut Sudira revealed his reflections.

So, the law of karma can be seen in that story. Whoever is guilty will receive the punishment accordingly. Even though they are vasu, if they do something wrong, they must get punishment. The law of karma still applies to anyone, including the gods. If the yams are 
planted, surely the yam also produced. It is impossible to have corn."

The story of the Goddess Ganga also evokes reflections that the birth as a human being is also a punishment. It is implied that the vasu who got the curse did not feel happy, if they were born as human beings in the world. They wanted to get the lightest punisments and begged for forgiveness from Rishi Wasistha. The age gave mercy and made the seven vasu felt relieved to live in the mortal world for only one day. From that story, according to Wayan Muliana, a literary aspirant from Tabanan, it can be contemplated that moksa is indeed the ultimate goal of humans. Muliana reflected on the story of the Goddess Ganga that vasu was an immortal creature. Thus, if they were born as human beings, that means there is a decrease in degree.

There is also another thing that should be contemplated, namely the curse is a blessing. If the curse in general is to have the connotation of punishment and to make the condemned one suffer, then the curse that Urvasi put on Arjuna is a blessing. Likewise, the curse of Queen Gandari was a blessing for Krishna. According to the story, Arjuna was cursed by Urvasi because her love was rejected.

However, the curse only lasted one year because of Lord Indra's request. The curse was used by Arjuna when he disguised himself one year in the Matsya Kingdom. At that time, Arjuna was a dance teacher and behaved as a transvestite.

A curse was also casted by Queen Gandari after the Bharatayuddha. When meeting Krishna, Queen Gandari, the Kaurava mother blamed Krishna for a civil war and all of her sons died. Subramaniam (2007: 762-763) writes it as follows.

I curse you. Because of your negligence, Kaurava and Pandava want to destroy each other. This world is ruined because of you. The animosity between these cousins has caused the destruction of the whole family. Therefore, in thirty-six years, from today, your family, the whole family of Vrsni, will destroy themselves.
The cousins will fight and kill each other. Women in your family will cry, like these women at this time. This is the curse of Gandhari.

Krsna smiled sweetly and said, Mother, I know that I am the only person capable of destroying the entire Vrsni family. They are not destroyed. They can only be destroyed by their own families. Only a Vrsni can kill a Vrsni. No one else can kill them. There is no god who can hurt them. They must die at the hands of their own siblings. I'm happy because your curse has helped me to solve my problem. I would have been forced to kill them all, if only you hadn't cursed me. Mother, I am truly very fortunate that you have worked together to destroy the Vrsni family. You really blessed me. There are also other things. Your anger has gone out now. You will never be able to get angry at Pandava again. I'm ready to do anything for Pandava. If my family has to be destroyed so they can live, I'm very happy to do it. I am telling you again that Pandava means more than my life.

The narrative above can also be contemplated that disaster or illness does not always mean suffering at all. Not infrequently, disaster is also a blessing.

The implication of the reader's affective aspect of Teo-Feminism education in the epic of Mahābhārata is that the wiracarita presents moral values that give rise to feelings, judgments and responses to those values. Feelings include sadness, anger, and joy. Feelings of sadness can be seen from the case of Princess Amba. She was one of the three princesses of the Kingdom of Kasi who was in a great contest for the warriors. She had chosen King Salva by draping a varmala. However, when Bhisma came and took the other Kasi's daughters, Princess Amba was also taken.

Princess Amba then told Bhisma that she had chosen Salva. Because of that, she returned to her palace again. Unfortunately, when Princess Amba met Salva, she was rejected. Salva suggested her to asked Bhisma to marry her. Princess Amba returned to meet 
Bhisma, but Ganga's son refused it because he did brahmacari that means he will not marry. As a result of that rejection, a reader of the Mahābhārata, Ni Made Dyah Sathya Pradnyadari, shared in the sadness experienced by Princess Amba. According to Pradnyadari (interviewed on 4 May 2019), how sad it would be if love was rejected. Moreover, all men who must marry her refused her love. As a woman who aspires to form a household, but then all those ideals fail, it is natural that Princess Amba feels sad. Furthermore, Pradnyadari claimed to be sad as follows.

As a normal woman, I feel sad when reading the story of Princess Amba. At first, she had chosen a man named Salva. From Salwa, she hoped that she would have children. Salwa was chosen as her husband and would accompany her both joy and sorrow. However, when she met Salva after being taken by Bhisma, even the man who had just chosen refused with a sarcastic laugh. I can feel the sadness of Princess Amba.

Because of it, Princess Amba wanted to take revenge on Bhisma in which she considered to be the cause of this suffering. Princess Amba did a long asceticism in the forest.

Pradnyadari also felt angry when he witnessed Draupadi being stripped by Dussasana in front of respectable people in Hastina. Pradnyadari imagined how cruel Dussasana was.

Based on Pradnyadari's statements above, she not only felt angry, but at the same time she also felt relieved because of having an assessment of the scene. As is already mentioned, Dussasana's actions were very barbaric and worse than animals' actions. It means there is a message conveyed that Dussasana has a very low nature and character. That figure is not worth mentioning human who have bayu, sabda and idep (wiweka), knowing which are good deeds and which are bad deeds. Dussasana is totally immoral who is devoid of morality

Regarding the evaluation of an act according to Pradnyadari, it can vary according to the case and its motivation. This can be seen in the case of Goddess Ganga and Queen Kunti. They both threw their biological children in the river, but those moments have different values because the motivations are different. Pradnyadari also stated that if she faced a problem like Queen Kunti, he also had difficulty in making decision. The story writer deliberately made a story like that to offer the reader a choice and make an assessment of the messages conveyed.

After reading the epic of Mahābhārata, a teacher or educator in the broadest sense takes actions such as spreading the message of the story to others through oral storytelling. They also have to analyze which actions should be imitated and which actions are not worth emulating.

Even though Queen Kunti had a mistake, there are many good points to emulating. According to Ni Nyoman Sunarti, Queen Kunti had firmness in maintaining her virginity. Even though she had never felt the pleasure of a 'biological interaction' with her husband in her life, she still maintained her holiness without ever intending to have an affair. She was so diligent and faithful to look after her sons, including her stepson. Kunti had once thrown Karna in the river, but she still prayed for her son to always find happiness. He did not mean to harm Karna at all.

According to Sunarti, a kindergarten teacher in South Denpasar, something that can be taken from the story of Queen Kunti is always begging the Gods for her children's survival. She also hopes that her children will always get along well in the family and she can be fair on her children.

However, according to Sunarti, she does not want to imitate Queen Gandari's attitude. The Kaurava's mother closed her eyes with cloth to show her loyalty to her blind husband. Dritarstra, who was blind from birth did not want to but Gandari deliberately made herself unable to see. If your husband cannot see because he has been blind since birth, why should you do the same thing? Sunarti added that this will cause an imbalance because she decided to close her eyes intentionally and the 
consequences can also be bad. She had heard the story from her late father about it. One day, Queen Gandari called her sons who was just a teenager to be resolved by applying elixir oil. Incidentally the first one who heard the call was Bhima. Kunti's son faced Queen Gandari who thought that the one who was coming was Duryodhana. Without asking first, Gandari rubbed Bhima's entire body with the elixir. After finishing, Gandari realized her mistake, but she tried to hide her disappointment. He again called his son, Duryodhana.

Gandari's eldest son immediately faced and the magic oil of the Gods' grace was rubbed over her son's body. Unfortunately, the oil was only enough to reach the thigh. For that reason, Duryodhana's thighs were weak while the other parts of his body could not be injured by weapons, both sharp and blunt weapons. In the Bharatayuddha war, Duryodhana's weakness was exploited by Bhima to win the duel. Therefore, Sunarti disagrees with the reason for being loyal to her husband and then makes herself blind or does not see deliberately. Moreover, the eye as a symbol of sight is a gift of God, so it is not wise if they are misused. Queen Gandari's attitude can be interpreted as the epic author's message that is offered to the readers for further reflection to be used as a way of life.

From the explanation above it can be concluded that the educational implications of the epic of Mahabharata have implications for someone who wants to learn (learning to know) as well as the readers of the epic of Mahabharata who read, listen or watch the epic of Mahabharata can take some values, like the concept of Dharma. After learning it, one can understand the teachings and attitude (learning to do), then the influence of the attitude that is instilled in oneself is formed into the character (learning to be) so that readers who regularly read and do the teachings will become accustomed to behaving (learning to live together).

\section{CONCLUSION}

There are four major implications of the Teo-Feminism narrated in the epic of
Mahābhārata. First, Leadership Implications are the influences of the Śhikhandi's spirit, and Draupadī's in providing leadership impact in this modern era. Second, Political Implications that affect the growing desire for women to enter politics which tends to be charged with a lot of household work. Next, Cultural Implications are influential in fighting for their rights and determining choices for their lives which consist of implications for the preservation of performing arts and implications for literary arts. The last implication is Educational Implications of the epic of Mahabharata which have implications for someone who wants to learn (learning to know), understand teachings and how to behave (learning to do), then the influence of attitudes that is instilled in oneself is formed into characters (learning to be) so that readers who regularly read and do the teachings will become accustomed to behaving (learning to live together).

\section{REFERENCES}

Darmayasa. (2017). Bhagawad Gita (Nyanyian Tuhan). Denpasar: Yayasan Dharma Sthapanam.

Emzir. S. R. (2015). Teori dan Pengajaran Sastra. Jakarta: Rajawali.

Gandi, M. (2002). Kaum Perempuan dan Ketidakadilan Sosial. Yogyakarta: Pustaka Pelajar.

Maksum, A. (2016). Sosiologi Pendidikan. Malang: Madani.

Poerwadarminta, W. J. S. (1987). Kamus Umum Bahasa Indonesia. Jakarta: Balai Pustaka.

Rajagopalachari, C. (2013). Kitab Epos Mahābhārata. Jakarta: IRCiSoD.

Sharma, K. A. (2013). PerempuanPerempuan Mahābhārata. Jakarta: Kepustakaan Populer Gramedia.

Suandewi, K. (2015). Mahābhārata ajaran agama Hindu yang Hidup dan Universal.(https://www.kompasiana.co m/suandewi/Mahābhārata-ajaranhindu-yang-hidup-danuniversal_55283c8af17e61fa2d8b45c). Accessed: 3 Mei 2018. 
Subramaniam, K. (2007). Mahābhārata. Surabaya: Paramita.

Suryani, L. K. (2003). Perempuan Bali Kini. Denpasar: BP

Titib, I M. (2003). Purāṇa Sumber Ajaran Hindu Komprehensip. Surabaya: Paramita.

Winanti, N. P. (2010). Perempuan dan Kepemimpinan Transformasional. Surabaya: Paramita.

Zoetmulder, P. J. (1995). Kamus Jawa Kuna Indonesia. Jakarta: Granmedia Pustaka Utama. 